\title{
DAMPAK KEKERASAN DALAM RUMAH TANGGA TERHADAP KARAKTER ANAK
}

\author{
${ }^{1}$ Edy Sofyan., SE, M.Pd \\ ${ }^{2}$ Ernandia Pandikar., SE, M.Pd \\ ${ }^{1}$ Dosen Program Studi Pendidikan Pancasila dan Kewarganegaraan \\ STKIP Pasundan \\ Email: kangedysofyan@gmail.com \\ ${ }^{2}$ Dosen Program Studi Pendidikan Pancasila dan Kewarganegaraan \\ STKIP Pasundan \\ Email: adhie.pandikar@gmail.com
}

\begin{abstract}
The family is the first environment in a child's life, a place where children learn and express themselves as social beings. The family provides the basis for the formation of behavior, character, morals and education of the child. Triggers of violence against children that occur among others are first, the emergence of domestic violence, the occurrence of violence involving both the father, mother and other relatives cause inevitable violence occurs also against children. Children are often targeted by parents' anger. Second, the occurrence of family dysfunction, namely the role of parents do not work as they should. Third, the economic factor, namely violence arises because of economic factors. The character of the child will be disturbed by the occurrence of wrong treatment that often escape the attention, whereas ordinary events are very often related, in the inability and ineffective parents in dealing with children. The problem formulation in this study is how big the role of parents according to legislation and norms prevailing in society, the factors causing the occurrence of violence in the household, and how big the character of children who experience violence in the household. The research method used a quantitative descriptive approach. As for the results from the average research scores the study mostly answered "Yes". With the overall average gain in the highest percentage score is $86.7 \%$ and the lowest percentage score is $13.3 \%$. So the conclusion of this study, domestic violence affecting the character of children in MTs.Az-zahra Selacau school in Selacau village, Batujajar sub-district, West Bandung regency.
\end{abstract}

Keywords: Domestic Violence, Child Character.

\begin{abstract}
ABSTRAK
Keluarga adalah lingkungan pertama dalam kehidupan anak, tempat dimana anak belajar dan menyatakan diri sebagai makhluk sosial. Keluarga memberikan dasar pembentukan tingkah laku, watak, moral dan pendidikan terhadap anak. Pemicu kekerasan terhadap anak yang terjadi diantaranya adalah pertama, munculnya kekerasan dalam rumah tangga, terjadinya kekerasan yang melibatkan baik pihak ayah, ibu dan saudara yang lainnya menyebabkan tidak terelakkannya kekerasan terjadi juga terhadap anak. Anak seringkali menjadi sasaran kemarahan orang tua. Kedua, terjadinya disfungsi keluarga, yaitu peran orang tua tidak berjalan sebagaimana seharusnya. Ketiga, faktor ekonomi, yaitu kekerasan timbul karena faktor ekonomi. Karakter anak akan terganggu dengan terjadinya perlakuan salah yang sering luput dari perhatian, padahal kejadian biasa sangat sering terkait, pada
\end{abstract}


ketidak mampuan dan kurang efektifnya orang tua dalam menghadapi anak. Adapun rumusan masalah dalam penelitian ini adalah seberapa besar peran orang tua menurut perundang-undangan dan norma yang berlaku dalam masyarakat, faktor-faktor penyebab terjadinya kekerasan dalam rumah tangga, dan seberapa besar karakter anak yang mengalami kekerasan dalam rumah tangga. Metode penelitian menggunakan pendekatan deskriptif kuantitatif. Adapun hasil dari penelitian skor rata-rata penelitian sebagian besar menjawab "Ya". Dengan perolehan rata-rata seluruhnya pada skor persentase tertinggi adalah 86,7\% dan skor persentase terendah adalah 13,3\%. Maka kesimpulan penelitian ini, kekerasan dalam rumah tangga berdampak terhadap karakter anak di sekolah MTs.Az-zahra Selacau di Desa Selacau Kecamatan Batujajar Kabupaten Bandung Barat.

\section{Kata Kunci : KDRT, Karakter Anak}

\section{PENDAHULUAN}

Indonesia merupakan negara kesatuan yang memiliki dasar hukum sebagai landasan dalam tata pemerintahan. Sebagai negara hukum, maka segala tindakan yang dilakukan oleh penduduk akan diikat, diatur, dan dilindungi oleh hukum yang berlaku di Indonesia. Hukum di Indonesia juga akan berlaku bagi seluruh warga Negara Indonesia walaupun warga tersebut berada di daerah kekuasaan negara lain. Perlindungan yang diberikan oleh hukum Indonesia memberikan rasa aman kepada masyarakat.

Salah satu bentuk hukum yang ada dan diatur dan dalam undang-undang adalah pernikahan. Pernikahan pada dasarnya adalah sama yaitu membentuk suatu keluarga yang bahagia dan kekal serta membangun, membina dan memelihara hubungan kekerabatan yang rukun dan damai di samping untuk memperoleh keturunan. Keluarga adalah unit terkecil dalam masyarakat yang terdiri dari suami istri, atau suami istri dan anaknya, atau ayah dan anaknya, atau ibu dan anaknya, atau keluarga sedarah dalam garis lurus keatas atau kebawah sampai dengan derajat ketiga.

Keutuhan dan kerukunan rumah tangga yang bahagia, aman, dan damai merupakan dambaan setiap orang dalam rumah tangga. Untuk mewujudkan keutuhan dan kerukunan tersebut sangat tergantung pada setiap orang dalam lingkup rumah tangga, terutama kadar kualitas perilaku dan pengendalian diri setiap orang dalam lingkup rumah tangga tersebut. Keutuhan dan kerukunan keluarga dapat terganggu jika kualitas dan pengendalian diri tidak dapat dikontrol,yang pada akhirnya terjadi kekerasan dalam rumah tangga sehingga, timbul ketidak amanan atau ketidak adilan terhadap orang yang berada dalam lingkup rumah tangga tersebut. Kedudukan anak dalam rumah tangga sebenarnya dalam posisi lebih lemah, lebih rendah karena secara fisik, mereka memang lebih lemah dari pada orang dewasa dan masih bergantung pada orang dewasa di sekitarnya.

Keluarga adalah lingkungan pertama dalam kehidupan anak, tempat dimana anak belajar dan menyatakan diri sebagai makhluk sosial. Keluarga memberikan dasar pembentukan tingkah laku, watak, moral dan pendidikan terhadap anak.

Pemicu kekerasan terhadap anak yang terjadi diantaranya adalah pertama, munculnya kekerasan dalam rumah tangga, terjadinya kekerasan yang melibatkan baik pihak ayah, ibu dan saudara yang lainnya menyebabkan tidak terelakkannya kekerasan terjadi juga terhadap anak. Anak seringkali menjadi sasaran kemarahan orang tua. 
Kedua, terjadinya disfungsi keluarga, yaitu peran orang tua tidak berjalan sebagaimana seharusnya.

Ketiga, faktor ekonomi, yaitu kekerasan timbul karena faktor ekonomi. Karakter anak akan terganggu dengan terjadinya perlakuan salah yang sering luput dari perhatian, padahal kejadian biasa sangat sering terkait, pada ketidak mampuan dan kurang efektifnya orang tua dalam menghadapi anak. Dengan di dasari akibat kekerasan terhadap anak, terjadinya gangguan pada kelangsungan hidup, perkembangan, perlindungan dan partisipasi anak, mulai dari luka psikologis sampai kematian yang jelas merupakan tindak pidana, masih belum tercapainya pemahaman makna kesepakatan bahwa anak adalah masa depan bangsa.

Kekerasan terhadap anak dengan alasan apapun tidak dapat dibenarkan. Kenyataan ini adalah setiap hari bahkan setiap menit ada anak yang menerima kekerasan dalam berbagai bentuk dan dengan kualitas yang berbeda beda. Masih banyak di daerah, anak-anak masih mengalami perlakuan salah antara lain tindakan kekerasan yang dilakukan orang tua terhadap anaknya, yang merupakan dampak dalam kekerasan rumah tangga. Anak adalah amanah dan karunia Tuhan YME yang dalam dirinya melekat harkat dan martabat sebagai manusia seutuhnya. Anak adalah tunas, potensi dan generasi muda penerus citacita perjuangan bangsa, memiliki peran strategis dan mempunyai sifat khusus yang menjamin kelangsungan eksistensi bangsa dan negara di masa depan.

Berdasarkan latar belakang yang telah diuraikan di atas, maka pada bagian ini penulis mengidentifikasi permasalahan, yaitu: dampak kekerasan dalam rumah tangga terhadap karakter anak.

Atas dasar identifikasi masalah tersebut diatas kemudian dibuat rumusan masalah dalam bentuk pertanyaan penelitian yang meliputi: a. Seberapa besar peran orang tua menurut perundang-undangan dan norma yang berlaku dalam masyarakat?

b. Faktor-faktor penyebab terjadinya kekerasan dalam rumah tangga?

c. Seberapa besar karakter anak yang mengalami kekerasan dalam rumah tangga?

\section{TINJAUAN PUSTAKA}

\section{Peran Orang Tua Menurut Undang- undang}

Adapun peranan orang tua yang sesuai dengan undang-undang yang berlaku di Negara Indonesia seperti yang tertera dalam Undang-undang Nomor 1 Tahun 1974 tentang Perkawinan, pasal 45 ayat 12: "ayat (1), kedua orang tua wajib memelihara dan mendidik anak-anak mereka sebaik-baiknya. Ayat (2), kewajiban orang tua yang dimaksud dalam ayat(1) pasal ini berlaku sampai anak itu kawin atau dapat berdiri sendiri kewajiban mana berlaku terus meskipun perkawinan antara kedua orang tua terputus".

Tanggung jawab orang tua atas kesejahteraan anak-anak mengandung kewajiban memelihara dan mendidik anak sedemikian rupa, sehingga anak dapat tumbuh dan berkembang menjadi orang yang cerdas, sehat, dan berbakti kepada orang tua, berbudi pekerti luhur, berbakti kepada Tuhan Yang Maha Esa dan berkemauan serta berkemampuan untuk meneruskan cita-cita bangsa berdasarkan Pancasila.

\section{Peran Orang Tua Menurut Norma Yang Berlaku di Masyarakat.}

Peranan orang tua dan didikannya sangat penting bagi kehidupan anak karena orang tua senantiasa menjadi contoh bagi kehidupan anak, dimana anak kelak bisa hidup di masyarakat dengan norma yang berlaku di dalam masyarakat tersebut tanpa ada rasa canggung. Norma sangat penting peranannya dalam kehidupan untuk mewujudkan kehidupan yang sesuai dengan harkat dan martabat manusia. Karena tanpa norma kehidupan masyarakat seperti kehidupan di dalam hutan 
belantara. Siapa yang kuat dialah pemenangnya. Dengan norma, setiap manusia memperjuangkan kepentingan dan kebutuhannya dalam batas-batas yang tidak melanggar aturan dan tidak merugikan kepentingan orang lain. Adapun norma-norma yang berlaku di masyarakat Indonesia menurut Agus Siswoyo (2014), ada 4 macam norma yaituh: Norma Agama, Norma Kesusilaan, Norma Kesopanan, dan Norma Hukum.

\section{Kekerasan Terhadap Anak}

Banyak orang tua menganggap kekerasan pada anak adalah hal yang wajar. Mereka beranggapan kekerasan adalah bagian dari mendisiplinkan anak. Mereka lupa bahwa orang tua adalah orang yang bertanggung jawab dalam mengupayakan kesejahteraan, perlindungan, peningkatan kelangsungan hidup, dan mengoptimalkan tumbuh kembang anaknya. Keluarga adalah tempat pertama kali anak belajar mengenal aturan yang berlaku di lingkungan keluarga dan masyarakat.

Barker (Huraerah, 2007: 47) "Kekerasan terhadap anak adalah tindakan melukai yang berulang-ulang secara fisik dan emosional terhadap anak yang ketergantungan, melalui desakan hasrat, hukuman badan yang tak terkendali, degradasi dan cemoohan permanen atau kekerasan seksual, biasanya dilakukan para orang tua atau pihak lain yang seharusnya merawat anak". Sedangkan menurut Richard J. Gelles (Huraerah, 2007: 47) "Kekerasan terhadap anak adalah perbuatan disengaja yang menimbulkan kerugian atau bahaya terhadap anak-anak secara fisik maupun emosional. Istilah child abuse meliputi berbagai macam tingkah laku, dari tindakan ancaman fisik secara langsung oleh orang tua atau orang dewasa lainnya sampai kepada penelantaran kebutuhankebutuhan dasar anak".

\section{Bentuk-bentuk Kekerasan Terhadap Anak}

Suharto

(1997:

365-366)

"mengelompokan child abuse menjadi: physical abuse (kekerasan secara fisik), psychological abuse (kekerasan secara psikilogis), sexual abuse (kekerasan secara seksual), dan social abuse (kekerasan secara sosial)". Keempat bentuk child abuse ini dapat dijelaskan sebagai berikut:

a. Kekerasan anak secara fisik, adalah penyiksaan, pemukulan, dan penganiayaan terhadap anak, dengan atau tanpa menggunakan benda-benda tertentu, yang menimbulkan luka-luka fisik atau kematian pada anak. Bentuk luka dapat berupa lecet atau memar akibat persentuhan atau kekerasan benda tumpul, seperti bekas gigitan, cubitan, ikat pinggang atau rotan. Dapat pula berupa luka bakar akibat bensin panas atau berpola akibat sundutan rokok atau setrika. Lokasi luka biasanya ditemukan pada daerah paha, lengan, mulut, pipi, dada, perut, punggung atau daerah bokong. Terjadinya kekerasan terhadap anak secara fisik umumnya dipicu oleh tingkah laku anak yang tidak disukai oleh orang tuanya, seperti anak nakal atau rewel, menangis terus, minta jajan, buang air, kencing atau muntah disembarang tempat, memecahkan barang berharga.

b. Kekerasan anak secara psikis, meliputi penghardikan, penyampaian kata-kata kasar dan kotor, memperlihatkan buku, gambar, dan film pornografi pada anak. Anak yang mendapatkan perlakuan ini umumnya menunjukan ngejala perilaku maladaftif, seperti menarik diri, pemalu, menangis jika didekati, takut ke luar rumah dan takut bertemu orang lain.

c. Kekerasan anak secara seksual, dapat berupa perlakuan pra-kontak seksual antara anak dan orang yang lebih besar (melalui kata, sentuhan, gambar visual, exhibitionism), maupun perlakuan kontak seksual secara langsung antara anak dengan orang dewasa (incest, perkosaan, eksploitasi seksual). 
d. Kekerasan anak secara sosial, dapat mencakup penelantaran anak dan eksploitasi anak. Penelantaran anak adalah sikap dan perlakuan orang tua yang tidak memberikan perhatian yang layak terhadap proses tumbuh-kembang anak. Misalnya, anak dikucilkan, diasingkan, dari keluarga, atau tidak diberikan pendidikan dan perawatan kesehatan yang layak. Eksploitasi anak menunjuk pada sikap diskriminatif atau perlakuan sewenang-wenang terhadap anak yang dilakukan keluarga atau masyarakat. Sebagai contoh, memaksa anak untuk melakukan sesuatu demi kepentingan ekonomi, sosial atau politik tanpa memperhatikan hak-hak anak untuk mendapatkan perlindungan sesuai dengan perkembangan fisik, psikisnya dan status sosialnya. Misalnya, anak dipaksa untuk bekerja di pabrik-pabrik yang membahayakan (pertambangan, sektor alas kaki) dengan upah rendah dan tanpa peralatan yang memadai, anak dipaksa untuk angkat senjata, atau dipaksa melakukan pekerjaan-pekerjaan rumah tangga melebihi batas kemampuannya.

\section{Faktor Penyebab Kekerasan} Terhadap Anak

Banyak orang tua menganggap kekerasan pada anak adalah hal yang wajar. Mereka beranggapan kekerasan adalah bagian dari mendisiplinkan anak. Mereka lupa bahwa orang tua adalah orang yang bertanggung jawab dalam mengupayakan kesejahteraan, perlindungan, peningkatan kelangsungan hidup, dan mengoptimalkan tumbuh kembang anaknya.

Barker (Huraerah, 2007: 47) "Kekerasan terhadap anak adalah tindakan melukai yang berulang-ulang secara fisik dan emosional terhadap anak yang ketergantungan, melalui desakan hasrat, hukuman badan yang tak terkendali, degradasi dan cemoohan permanen atau kekerasan seksual, biasanya dilakukan para orang tua atau pihak lain yang seharusnya merawat anak".

Secara rinci Rusmil (Huraerah: 2007:53), membagi penyebab kekerasan terhadap anak dalam 3 (tiga) kelompok yaitu: faktor orang tua atau keluarga, faktor lingkungan sosial atau komunitas, dan faktor anak itu sendiri.

Suharto (1997: 366-367) "kekerasan terhadap anak umumnya disebabkan oleh faktor internal yang berasal dari anak sendiri maupun faktor eksternal yang berasal dari kondisi keluarga dan masyarakat. Faktor-faktor internal tersebut antara lain anak mengalami cacat tubuh, retardasi mental, gangguan tingkah laku, autisme, anak terlalu lugu, memiliki temperamen lemah, ketidak tahuan anak akan hak-haknya, anak terlalu bergantung terhadap orang dewasa". Faktor eksternal yang berasal dari kondisi keluarga dan masyarakat antara lain: kemiskinan keluarga, keluarga tunggal atau keluarga pecah (broken home), keluarga yang belum matang secara psikologis, penyakit parah atau gangguan mental pada salah satu atau kedua orang tua, sejarah penelantaran anak, dan kondisi lingkungan sosial yang buruk.

\section{Dampak Akibat Kekerasan Terhadap Anak \\ Rusmil (Huraerah, 2007:56)} mengemukakan bahwa anak-anak yang menderita kekerasan, eksploitasi, pelecehan dan penelantaran menhadapi resiko: usia yang lebih pendek, kesehatan mental dan fisik yang buruk, masalah pendidikan (termasuk dropt-out dari sekolah), kemampuan yang terbatas sebagai orang tua kelak, dan menjadi gelandangan.

Sementara itu, YKAI (Yayasan Kesejahteraan Anak Indonesia) dalam Suharto (1997: 367-368) menyimpulkan bahwa kekerasan dapat menyebabkan anak kehilangan hal-hal yang paling mendasar dalam kehidupannya dan pada gilirannya berdampak sangat serius pada kehidupan anak dikemudian hari, antara lain: cacat 
tubuh permanen, kegagalan belajar, gangguan emosional bahkan dapat menjurus pada gangguan kepribadian, konsep diri yang buruk dan ketidak mampuan untuk mempercayai atau mencintai orang lain, pasif dan menarik diri dari lingkungan, takut membina hubungan baru dengan orang lain, agresif dan kadang-kadang melakukan tindakan criminal, menjadi penganiaya ketika dewasa, menggunakan obat-obatan atau alcohol, dan kematian.

\section{Karakter Anak}

Karakter berasal dari bahasa yunani yaitu: "kharrasein" yang berarti memahat atau mengukir (to inscribe/to engrave), Narwanti (2011: 11) "dalam bahasa latin, karakter bermakna membedakan tanda, sifat,kejiwaan, tabiat, dan watak". Sjarkawi (2006: 1) "karakter adalah ciri atau karakteristik atau gaya atau sifat khas dari diri seseorang yang bersumber dari bentukan-bentukan yang diterima dari lingkungan, misalnya keluarga pada masa kecil, dan juga bawaan seseorang sejak lahir".

Koesoema (2010: 3) "karakter merupakan struktur antropologis manusia, di sanalah manusia menghayati keterbatasan dirinya". Narwanti (2011: 3) "karakter adalah suatu sifat yang tertanam dalam diri seseorang dan sifat itu akan timbul disetiap ia bertindak tanpa merasa sulit (timbul dengan mudah) karena sudah menjadi budaya sehari-hari”.

Undang-undang nomer 20 tahun 2003 tentang pendidikan pada pasal 3, “...yang berbunyi pendidikan nasional berfungsi mengembangkan kemampuan dan membentuk karakter serta peradaban bangsa yang bermartabat dalam rangka mencerdaskan kehidupan bangsa". Karakter seseorang dikatakan baik apabila sesuai dengan norma atau aturan yang berlaku pada masyarakat, Negara maupun bangsa.

Anak adalah seseorang yang belum berusia 18 (delapan belas)Tahun, termasuk anak yang masih dalam kandungan.
Macam-macam pengertian tentang anak diantaranya : anak terlantar, anak cacat, anak memiliki keunggulan, anak angkat dan anak asuh.

Berdasarkan uraian diatas, maka dapat disimpulkan Kekerasan terhadap anak adalah segala bentuk perlakuan baik secara fisik maupun psikis yang berakibat penderitaan terhadap anak. Sedangkan karakter adalah suatu sifat yang ada dalam diri seseorang yang terbentuk atau masih bisa di bentuk dalam pergaulan sehari-hari. Lingkungan keluarga sangatlah berpengaruh terhadap karakter anak karena keluarga memberikan dasar pembentukan tingkah laku, watak, moral dan pendidikan terhadap anak.

Karakter anak akan terganggu dengan terjadinya perlakuan salah yang sering luput dari perhatian, padahal kejadian biasa sangat sering terkait, pada ketidak mampuan dan kurang efektifnya orang tua dalam menghadapi anak.

\section{METODOLOGI}

Metode penelitian menggunakan pendekatan deskriptif kuantitatif. Metode ini digunakan untuk mengkaji variabel yang ada pada penelitian

Data yang diperoleh penyusunan bersifat kuantitatif dengan skala Guttman sehingga perlu diolah untuk menarik kesimpulan. Teknik analisis data yang digunakan adalah teknik hitung analisis deskriptif untuk mendeskripsikan variabel penelitian dalam pengukuran dan tidak menggunakan statistik inferensial karena tidak ada hipotesis dalam penelitian ini.

Adapun teknik statistik yang digunakan dalam penelitian ini adalah persentase. Persentase untuk setiap kemungkinan jawaban diperoleh dari membagi frekuensi yang diperoleh dengan jumlah sampel, kemudian dikalikan $100 \%$.

\section{HASIL PENELITIAN}

Pelaksanaan pengukuran uji lapangan dalam pengembangan instrumen dampak kekerasan dalam rumah tangga terhadap karakter anak melibatkan 53 responden siswa-siswi Mts. Az-zahra Selacau yang di 
bagi 6 kelas yang berbeda dengan pembagian uji lapangan kelas di mulai kelas 7A,7B,8A,8B,9A dan 9B. Jumlah dari kelas 7A adalah 9 responden, kelas 7B adalah 9 responden, kelas $8 \mathrm{~A}$ adalah 9 responden, kelas $8 \mathrm{~B}$ adalah 9 responden, kelas 9A adalah 9 responden dan kelas 9B adalah 8 responden. Pelaksanaan uji lapang akan dilakukan secara bertahap yang dimulai dari kelas 7A, 7B, 8A, 8B, 9A dan 9B. Uji coba lapang kelas 7A dan 7B dilakukan pada hari jum'at, tanggal 01 September 2017 di Mts.Az-zahra Selacau, uji coba lapang kelas 8 a dan $8 \mathrm{~B}$ dilakukan pada hari senin tanggal 04 September 2017 di Mts.Az-zahra Selacau, dan uji coba lapang kelas 9A dan 9B dilakukan pada hari rabu tanggal 06 September 2017 di Mts.Az-zahra Selacau. Pelaksanaan dilakukan pada saat jam istirahat di kelas masing-masing responden.

\section{a. Kelas 7A}

Hasil uji validitas instrumen terhadap domain dampak kekerasan dalam rumah tangga terhadap karakter anak $r_{\text {hit }}>3,00$ terhadap 9 responden adalah 36 (100\%) butir pertanyaan valid. Tahap uji lapang dampak kekerasan dalam rumah tangga terhadap karakter anak terdapat $1(11,2 \%)$ responden menjawab "Tidak" dan 8 (88,8\%) responden menjawab "Ya".

\section{b. Kelas 7B}

Hasil uji validitas instrumen terhadap domain dampak kekerasan dalam rumah tangga terhadap karakter anak $r_{\text {hit }}>3,00$ terhadap 9 responden adalah $36(100 \%)$ butir pertanyaan valid. Tahap uji lapang dampak kekerasan dalam rumah tangga terhadap karakter anak terdapat $1(11,2 \%)$ responden menjawab "Tidak" dan 8 $(88,8 \%)$ responden menjawab "Ya".

\section{c. Kelas 8A}

Hasil uji validitas instrumen terhadap domain dampak kekerasan dalam rumah tangga terhadap karakter anak $r_{\text {hit }}>3,00$ terhadap 9 responden adalah 36 (100\%) butir pertanyaan valid. Tahap uji lapang dampak kekerasan dalam rumah tangga terhadap karakter anak terdapat $1(11,2 \%)$ responden menjawab "Tidak" dan 8 $(88,8 \%)$ responden menjawab "Ya".

\section{d. Kelas 8B}

Hasil uji validitas instrumen terhadap domain dampak kekerasan dalam rumah tangga terhadap karakter anak $r_{\text {hit }}>3,00$ terhadap 9 responden adalah 36 (100\%) butir pertanyaan valid. Tahap uji lapang dampak kekerasan dalam rumah tangga terhadap karakter anak terdapat $2(22,3 \%)$ responden menjawab "Tidak" dan 7 $(77,7 \%)$ responden menjawab "Ya".

\section{e. Kelas 9A}

Hasil uji validitas instrumen terhadap domain dampak kekerasan dalam rumah tangga terhadap karakter anak $r_{\text {hit }}>3,00$ terhadap 9 responden adalah 36 (100\%) butir pertanyaan valid. Tahap uji lapang dampak kekerasan dalam rumah tangga terhadap karakter anak terdapat $1(11,2 \%)$ responden menjawab "Tidak" dan 8 $(88,8 \%)$ responden menjawab "Ya".

\section{f. Kelas 9B}

Hasil uji validitas instrumen terhadap domain dampak kekerasan dalam rumah tangga terhadap karakter anak $r_{\text {hit }}>3,00$ terhadap 8 responden adalah $36(100 \%)$ butir pertanyaan valid. Tahap uji lapang dampak kekerasan dalam rumah tangga terhadap karakter anak terdapat $1(12,5 \%)$ responden menjawab "Tidak" dan 7 $(77,7 \%)$ responden menjawab "Ya".

Tabel 4.8

\begin{tabular}{|c|c|c|c|c|c|c|c|c|c|c|c|c|}
\hline \multirow{2}{*}{ Jawaban } & \multicolumn{2}{|c|}{ Kelas 7A } & \multicolumn{2}{|c|}{ Kelas 7B } & \multicolumn{2}{c|}{ Kelas 8A } & \multicolumn{2}{c|}{ Kelas 8B } & \multicolumn{2}{c|}{ Kelas 9A } & \multicolumn{2}{c|}{ Kelas 9B } \\
\cline { 2 - 12 } & f & P & f & P & f & P & f & P & f & P & f & P \\
\hline Ya & $\mathbf{8}$ & $\mathbf{8 8 , 8 \%}$ & $\mathbf{8}$ & $\mathbf{8 8 , 8 \%}$ & $\mathbf{8}$ & $\mathbf{8 8 , 8 \%}$ & $\mathbf{7}$ & $\mathbf{7 7 , 7} \%$ & $\mathbf{8}$ & $\mathbf{8 8 , 8} \%$ & $\mathbf{7}$ & $\mathbf{8 7 , 5} \%$ \\
\hline Tidak & $\mathbf{1}$ & $\mathbf{1 1 , 2 \%}$ & $\mathbf{1}$ & $\mathbf{1 1 , 2 \%}$ & $\mathbf{1}$ & $\mathbf{1 1 , 2 \%}$ & $\mathbf{2}$ & $\mathbf{2 2 , 3 \%}$ & $\mathbf{1}$ & $\mathbf{1 1 , 2 \%}$ & $\mathbf{1}$ & $\mathbf{1 2 , 5 \%}$ \\
\hline
\end{tabular}


Berdasarkan hasil penelitian dalam tabel 4.8 dapat diketahui jawaban afektif 53 responden siswa-siswi Mts.Az-zahra selacau kelas 7 sampai kelas 9 dalam uji lapang untuk kategori dampak kekerasan dalam rumah tangga terhadap karakter anak, di dapat hasil yang reliabel dengan nilai $r_{n}=0,411$ untuk variabel kekerasan dalam rumah tangga $(\mathrm{X})$ dan $r_{n}=0,425$ untuk variabel karakter anak (Y). Sehingga data tersebut menunjukan bahwa terdapat 46 responden menjawab "Ya" dan 7 responden menjawab "Tidak". Skor ratarata penelitian dampak kekerasan dalam rumah tangga terhadap karakter anak sebagian besar menjawab "Ya". Dengan perolehan rata-rata seluruhnya pada skor persentase tertinggi adalah $86,7 \%$ dan skor persentase terendah adalah $13,3 \%$.

\section{KESIMPULAN}

peran orang tua merupakan hal yang paling dasar dan sangat berpengaruh dalam pembentukan karakter anak. Pendidikan yang diterapkan sejak dini membuat anak mempunyai kepribadian dan perilaku yang sesuai dengan pendidikannya di dalam rumah tangga. Peran orang tua menjadi titik sentral dalam menanamkan kebiasaan di keluarga. Orang tua wajib mendidik anaknya karena merupakan karena merupakan suatu anugerah dan telah di amanatkan dalam undang-undang yang berlaku di Indonesia maupun Dunia Internasional. Maka kesimpulan penelitian ini, kekerasan dalam rumah tangga berdampak terhadap karakter anak.

Maka dapat disimpulkan Kekerasan terhadap anak adalah segala bentuk perlakuan baik secara fisik maupun psikis yang berakibat penderitaan terhadap anak. Sedangkan karakter adalah suatu sifat yang ada dalam diri seseorang yang terbentuk atau masih bisa di bentuk dalam pergaulan sehari-hari. Lingkungan keluarga sangatlah berpengaruh terhadap karakter anak karena keluarga memberikan dasar pembentukan tingkah laku, watak, moral dan pendidikan terhadap anak.

\section{DAFTAR REFERENSI}

\section{Buku :}

Arikunto, S. (2010). Prosedur Penelitian Suatu Pendekatan Praktik. Jakarta: PT Rineka Cipta.

Azwar, S. (2012). Metode Penelitian.

Yogyakarta:

Pustaka Pelajar.

Effendy, U. (2014). Dinamika Komunikasi.

Bandung: PT. Remaja Rosdakarya.

Huraerah, Abu. (2007). Kekerasan

Terhadap Anak.

Bandung: Nuansa.

Kansil, C.S.T dan Christine S.T. Kansil. 2006. Modul Pendidikan Pancasila dan Kewarganegaraan. Jakarta: PT. Pradnya Paramita.

Koesdiyo, R Poerwanto. 2007. Pendidikan Pancasila. Yogyakarta: Graha Ilmu.

Koesoema, D. (2010). Pendidikan Karakter Strategi Mendidik Anak di Zaman Global. Jakarta: Grasindo.

Narwanti, S. (2011). Pendidikan Karakter Pengintegrasian 18 Nilai dalam Mata Pembelajaran. Yogyakarta: Familian.

Purwadarminto. 1998. Kamus Besar Bahasa Indonesia. Jakarta: Balai Pustaka.

Siregar, S. (2013). Metode Penelitian Kuantitatif Dilengkapi Perbandingan Perhitungan Manual \& SPSS. Jakarta: Kencana.

Sjarkawi. (2006). Pembentukan

Kepribadian Anak.

Jakarta: Bumi Aksara.

Sugiyono. (2012). Metode Penelitian Kuantitatif Kualitatif dan $R \& D$. Bandung: Alfabeta.

Suharsaputra, U. (2012). Metode Penelitian Kuantitatif, Kualitatif, dan Tindakan Kelas. Bandung: Refika Aditama.

Suharto, E. (1997). Pembangunan, Kebijakan Sosial, dan Pekerjaan Sosial. 
Bandung: Lembaga Studi Pembangunan-Sekolah Tinggi Kesejahteraan Sosial.

Widjaja, A. W. (1985). Manusia Indonesia, Individu, Keluarga \& Masyarakat. Jakarta: Akademika Pressindo.

Winataputra, Udin S dan Budimansyah Dasim. 2007. Civic Education. Bandung: Program Studi Pendidikan Kewarganegaraan.

Yaumi, M. (2014). Pendidikan Karakter. Jakarta: Prenadamedia Group.

Sumber Skripsi, Jurnal, Internet dan Lain-lain :

Alfiyah. (2012). Peran Orang Tua Dalam Membentuk Karakter Anak. Makalah. Terbit : $\quad$ http:// alfiyah90.wordpress.com> peranorangtua-dalam-membentuk-karakteranak. (30 nov 2012).

Anggadewi, B. E. T. (2007). Studi Kasus Tentang Dampak Psikologis Anak Korban Kekerasan Dalam Rumah Tangga. Skripsi pada Universitas Sanata Dharma Yogyakarta. Terbit: http: // repository.usd.ac.id>029114088_full.pd f.

Bagja, A. R. T. (2016). Pengaruh Pola Asuh Orang Tua Terhadap Pembentukan Karakter Anak di Desa Budiharja Kecamatan Cililin Kabupaten Bandung Barat. Skripsi. (Tidak Diterbitkan). STKIP Pasundan Cimahi.

Daulay, W. (2015). Persepsi Ibu Tentang Fungsi Keluarga di Kelurahan Merdeka Kecamatan Medan Baru Padang Bulan Medan. Chapter II. Pdf. 9.

Herdiana, Heri. (2012). Kekerasan Orang Tua Terhadap Anak di Hubungkan
Dengan Undang-undang Nomor 23 Tahun 2002 Tentang Perlindungan Anak. Makalah. Terbit: herdianaheri.blogspot.com> 2012/05> kekerasanorangtuaterhadapanakdihubun gkandenganundangundangnomoe 23 tah un2002.

Ikawati dan Rusmiyati. (2003). Kekerasan Terhadap Anak Dalam Keluarga dan Upaya Penanganannya. (Sebuah Jurnal). Jakarta: Media Informasi Penelitian.

Lidyasari, A. T. (2011). Pola Asuh Otoritatif Sebagai Sarana Pembentukan Karakter Anak dalam Setting Keluarga. Artikel Pola Asuh, 1-2.

Munggaran, Djati Rizky. (2012). Pemanfaatan Open Source Software Pendidikan Oleh Mahasiswa Dalam Rangka Implementasi Undang-undang No. 19 Tahun 2002 Tentang Hak Cipta. Skripsi. Terbitan : Repository.Upi.Edu.

Munir, Sahrul. (2013). Peranan Orang Tua Dalam Pendidikan Anak. Makalah. Terbitan: mohsahrulmunir.blogspot.com> 2013/06.

Siswoyo, Agus. (2013). Macam-macam Norma Yang Berlaku Di Masyarakat Indonesia. Makalah. Terbit : agussiswoyo.com> kewarganegaraan. ( 9 ags 2013)

\section{Undang-undang RI :}

Undang-undang Nomor 1 Tahun 1974, Tentang Perkawinan.

Undang-undang Nomor 23 Tahun 2002, Tentang Perlindungan Anak.

Undang-undang Nomor 39 Tahun 1999, Tentang Hak Azasi Manusia.

Undang-undang Dasar 1945 Pasal 28B ayat 2 . 